\title{
Hegemony and Humanitarian Norms: The US Legitimation of Toxic Violence
}

\author{
Eric Bonds \\ University of Mary Washington \\ ebonds@UMW.edu
}

\begin{abstract}
Despite widespread beliefs that the United States has not used chemical weapons since the distant past of World War I, this study suggests a more complicated history by examining U.S. use of herbicides and incapacitating gases in the Vietnam War and its use of herbicides in the "War on Drugs." This article places such use of toxic violence within a context of U.S. hegemony, by which U.S. officials have used contested forms of violence to secure geopolitical goals, but have also been pressured to comply with humanitarian norms or-when there is a gap between norms and state policy - to do legitimating work in order to maintain domestic and international consent. Based on case study analysis of archival and secondary sources, this article identifies three main techniques U.S. officials use to legitimate contested forms of violence. These techniques are defensive categorization, humanitizing discourse, and surrogacy.
\end{abstract}

Keywords: legitimation, hegemony, humanitarian norms, chemical weapons, Vietnam War, War on Drugs

The world economic and political system has long been uneasily saddled with the ideology of centrist liberalism, a "geoculture" that promises incremental and moderate reforms to guarantee political and social rights (Wallerstein 1995, 2011). One important component of global liberalism has been the century-old effort to reform and humanize war, in which state governments and civil society actors have sought to promote humanitarian norms, formalized through international treaty-making, as a means of prohibiting certain forms of state violence that have been identified as especially indiscriminate or inhumane. But like the political ideology of liberalism as a whole, this is often irreconcilable with the realities of the world-system, which is premised upon the threat and actual use of mass violence between states as they vie with one another over territory and as they work to promote the continuous accumulation of capital (see Arrighi 2010).

This contradiction - between liberal humanitarianism and the realities of the structure of the world-system - poses significant challenges to policymakers, especially those in the United States where, as a hegemonic power, the contradiction may become most acute. As a hegemonic power, the United States has had disproportionate capacity to shape and benefit from the 
contours of the world's political economy in the past half century ${ }^{1}$ (Wallerstein 2004; Arrighi 2010). Exercising hegemony, however, necessitates more than simply achieving military and economic dominance (Arrighi and Silver 1999). It also means that a global power must earn the consent of the governed by providing global moral leadership and making a convincing case that it represents a general - as opposed to its own particular - interest in world affairs (Arrighi and Silver 1999), which in contemporary times has often meant upholding broadly-shared humanitarian norms. While it is clear that both coercion, achieved through real or threatened military violence, and consent, achieved through cultural appeal, are both necessary components of hegemony, it is important to ask, when these needs are contradictory, which trumps the other, and why? Through the course of this article, I work to answer these questions in a case-study of U.S. toxic weapons policy from 1961 to the present time.

There is a longstanding and broadly-shared norm that stigmatizes and prohibits the use of chemical weapons (Price 1997). It is widely presumed that the United States has not utilized chemical weapons since World War I, after which they were outlawed and condemned by the Geneva Protocol of 1925. But, as is documented here, actual events are much more complicated and tend to contradict conventional understandings. In this paper, I make the analytic distinction between toxic violence and chemical weapons. Toxic violence is a broad category in which implements of force are used primarily for their chemically toxic qualities. ${ }^{2}$ Chemical weapons, however, are a subset within the larger category of toxic munitions that have been internationally banned as such. So, while it might appear that the strong norm expressed in the Geneva Protocol - first signed by the U.S. in 1925 and then ratified in 1975 - has steered the U.S. away from the use of toxic violence when it outlawed the use of "asphyxiating, poisonous, or other gases, and of all analogous liquids, materials, or devices," an examination of U.S. policy tells a different story.

In this study of U.S. policy development regarding toxic violence, I make the case that long-standing and broadly-shared humanitarian norms, even those regarding chemical weapons, have not necessarily prevented the U.S. from using stigmatized or prohibited forms of violence in its pursuit of hegemony. Rather, I argue that the United States has sought to maintain a distinction between certain forms of toxic violence. On the one hand, the United States has abided by international norms regarding chemical weapons by abdicating the use of immediately lethal chemicals. Doing so was certainly in the United States' hegemonic interest because it strengthened efforts to prevent militarily-weak nations from developing their own chemical weapon stockpiles that could be real deterrents to invasion from a Western power (Price 1997). On the other hand, the United States has not strictly complied with the norm by abandoning all forms of toxic violence, but has widely used other chemicals in wars and violent conflicts, such as the herbicides and incapacitating gases widely used in Vietnam, as well as herbicides used in the "War on Drugs." The cases in this study show, however, that any use of toxic violence is contested and condemned as a breach of international humanitarian norms. Its use, therefore, requires that U.S. officials do legitimating work.

\footnotetext{
${ }^{1}$ The author certainly acknowledges the contemporary decline of U.S. power, which has lead notable world-systems researchers to determine that the U.S. no longer remains a hegemonic state (Wallerstein 2003; Arrighi 2010). However, this paper mainly focuses on the periods between 1961 and 2000, in which it can safely be said that the U.S. exercised hegemony, even if in a period of decline.

${ }^{2}$ While the lead in bullets or the depleted uranium in anti-armor shells is chemically toxic, neither is used primarily for its toxicity. Such weapons do not constitute methods of toxic violence by the definition used here.
} 
The cases investigated here demonstrate that U.S. policymakers have consistently employed three main techniques of legitimation in efforts to justify, obfuscate, or distance themselves from uses of toxic violence: defensive categorization, humanitizing discourse, and surrogacy. Through defensive categorization, officials deny that the U.S. government has violated an international standard. In doing so, officials work to normalize such contested violence by stressing its routine, everyday nature. Through what I call humanitizing discourse, officials emphasize the care taken to avoid humanitarian harm when the U.S. government uses a contested form of violence, and indeed may even claim that the use of such violence has humanitarian benefits. Through surrogacy, the U.S. provides another state or armed group the means of carrying out contested acts of violence, providing U.S. officials some plausible deniability that they are responsible for any resulting violations of humanitarian norms. Such legitimating techniques may be very useful to officials working to manage the inherent contradictions of hegemony in our particular time.

\section{Managing the Contradictions of Hegemony}

According to Wallerstein (1995), the "ideological cement" of the world-economic system has been the geoculture of centrist liberalism, which has two fundamental components. First, centrist liberalism, like all forms of liberalism, proclaims the "sovereignty of the people." Second, it promises methodical reform of existing conditions to increase political and economic equality as a means toward its achievement (Wallerstein 2011). Centrist liberalism has legitimated global capitalism by providing a political program that promised concessions as a means of placating and controlling the "dangerous classes." However, it has always been at odds with, and continuously contradicted by, the structural realities of the world-system, which require stark inequalities between peoples and the continuous geopolitical rivalries between states (Wallerstein 2003; 2011).

Nowhere is this contradiction more apparent than that between the efforts to reform and "humanize" war in the past century and the reality of military violence during the same period. Beginning in the late $1800 \mathrm{~s}$, states and civil society actors sought to fulfill the promise of liberalism by reforming warfare through the introduction of a number of normative restraints, such as securing protections for captured or wounded soldiers, protecting civilian populations, enacting universal prohibitions on certain weapons, and even promoting disarmament (Roberts 1994). While efforts toward disarmament failed, multilateral treaties emerged that have since come to be called the "Laws of War." These international agreements resulted in bans on certain kinds of weapons and, through the Geneva Conventions formalized between 1886 and 1929, sought to impose more general restraints on war-fighting (Roberts 1994). Altogether, the outcome of these liberal efforts to reform war is an international normative framework that attempts to outlaw certain forms of state violence, such as the use of chemical weapons, torture, and the deliberate targeting of civilians. Some scholars have argued that such international norms have had a real impact on state behavior (see Finnemore 1996; Price 1997; Wotipka and Tsutsui 2008; Koo and Ramirez 2009). A careful study of U.S. violence may, however, require that such assertions be tempered.

Certainly, the United States could not shrug off or ignore the emergence of humanitarian norms in its pursuit of hegemony during the twentieth century. Hegemony requires, after all, that a dominant nation exercise the global "moral leadership" necessary to garner the consent of a 
critical mass of domestic and international political factions (Arrighi 2010). Likely for this reason, the United States became the "world spokesman for liberalism" during its era of hegemony, promoting the idea of the "rights of the people," including the notion that they should not be deprived of their most basic rights to life during times of war (Wallerstein 1995: 156). Furthermore, several scholars have argued that powerful nations work to establish global humanitarian norms as a means of controlling or diminishing the military capacities of weaker nations or insurgent non-state groups, as in the case of chemical weapons (Price 1997), landmines (Beier 2011), or the small arms trade (Stavrianakis 2011). Hegemony, however, requires more than an economically dominant nation's ability to exert global cultural leadership; it also requires the use of violent coercion (Arrighi 2010; see also Gramsci 1971).

There are several reasons why military force is particularly important to the U.S. during its era of hegemony. First and foremost, the United States was called upon to secure "international order," including the maintenance of inequitable relationships between nations first forged through colonialism (Wallerstein 2004). Securing "international order" has often meant that the United States has used its military power to open and preserve access to foreign markets and to protect its own military and economic supremacy. It has also used its substantial military power as a threat or through actual belligerence in order to maintain access to valuable natural resources that are necessary for the continuous accumulation of capitalism (Klare 2004; Downey, Bonds, and Clark 2010). In sum, the period of U.S. hegemony has been one in which the U.S. military was continuously poised to use coercive violence to defend the established world order, and one in which it was often embroiled in one conflict or another somewhere around the globe.

There is, therefore, a real contradiction that U.S. officials had to manage during the period of U.S. hegemony; in order to secure international and domestic consent, officials had to proclaim the values of liberalism and act to protect the "rights of the people," even in times of war. This presented some pressure to comply with international humanitarian norms that prohibit and stigmatize certain acts of violence that have been identified as especially cruel or harmful. On the other hand, ensuring U.S. hegemony required the consistent use of military force that, at times, resulted in widespread killings that deprived unarmed persons of their most basic right to exist. Such contradictions have typically been managed, which is to say actively suppressed, through appeals to "military necessity" and through the dehumanization of real or potential "enemies." Through these appeals, officials attempt to justify acts of egregious violence by claiming that they are necessary for victory or even survival. Through processes of dehumanization, aided and abetted by longstanding notions of white supremacy, state officials and other elites may portray enemy populations as subhuman, inhuman, or as being barbarous and therefore outside the bounds of civilization (Dower 1987; Steuter and Wills 2008). Such symbolic treatment of others may suppress the contradiction between the humanitarian norms that emerged during the period of liberal reformism and the brutal and altogether inhumane realities of actual state violence that characterize it.

Though appeals to military necessity and the dehumanization of enemies have been important means by which the United States has historically legitimated wars and mass violence, they may not by themselves be sufficient in the contemporary era. This is particularly due to anti-colonial and anti-racist struggles that have countered dehumanization and sought to affirm the humanity of all persons, along with the development of global human rights networks that seek to publicize and shame state practices that violate international normative frameworks (Risse, Ropp, and Sikkink 1999; Wallerstein 2004; Blau and Moncado 2005). Historical research 
presented in this article indicates that the U.S. government has utilized three additional techniques to do legitimating work as a means of attempting to hide, distance itself from, or explain away perceived violations of international humanitarian norms. These techniques include defensive categorization, the use of humanitizing discourse, and surrogacy.

\section{Defensive Categorization}

Governments that are criticized for committing atrocities or violations of humanitarian norms often categorically deny all accusations (Cohen 2001). There are some situations, however, when certain facts about contested acts of state violence are undeniable and beyond dispute. In such instances, state officials often seek to place these acts and outcomes within an interpretative framework through which they would not be considered major violations of humanitarian norms (Cohen 2001). Defensive categorization is one such technique, by which U.S. governmental officials attempt to make the case that a certain act of state violence is quite different and altogether separate from another stigmatized category of violence. Instead, officials attempt to normalize such acts by stressing how similar they are to routine and commonplace behavior.

\section{Humanitizing Discourse}

U.S. officials may further attempt to legitimate contested forms of violence through the use of a humanitizing discourse, by which they may stress the extreme care that their military takes to avoid humanitarian harms when using contested weaponry. Of course, such claims are often misleading and may, in some situations, simply not be true. U.S. governmental officials may also use a humanitizing discourse in defense of contested forms of violence by stressing their alleged humanitarian benefits. For instance, wars are increasingly justified in recent times as being fought in the interest of human rights and democracy (Bricmont 2006).

\section{Surrogacy}

Through this legitimating technique, U.S. officials can direct client states to utilize weapons or violent practices that breach international humanitarian norms, often supplying these governments with the means to do so. Surrogacy provides the United States distance and/or the ability to argue that it is not ultimately responsible for any resulting violations of international standards committed by its adjuncts (Bonds 2012).

Through the remainder of this article, I will examine three historical instances where the United States has used chemically toxic weapons from the 1960 s to the present, documenting the consistency through which these three legitimating techniques were used.

\section{The U.S. Use and Legitimation of Toxic Violence}

It is widely presumed that the United States, like all Western nations, disavowed the use of chemical weapons in the aftermath of World War One and has not used them since. Richard Price $(1995,1997)$ tells one such story when arguing that there is a very powerful chemical weapons "taboo" in global political culture that has had a real impact on the development of state policy. Price argues that attention to this norm is necessary to explain why immediately lethal 
chemical weapons - of the sort used during World War One-have not been used since by Western nations and, more generally, why chemical weapons have been used so little in recent times. Price argues that this is not simply due to a supposed lack of military utility, as chemical weapons could be used very effectively by modern militaries to kill large numbers of people and sow terror in an enemy population, which are outcomes often valued by military planners. ${ }^{3}$

To Price, the effectiveness of this norm has much to do with the political power of Western nations and their own military interests. Ever since a global norm stigmatizing chemical weapons was developed and formalized in global political culture, according to Price (1995: 95), it has "come to function as a symbol of the hierarchical relations of domination in the international system." The first nations to commit to the non-use of chemical weapons were "civilized" states and, as the argument goes, non-Western states banned their use in emulation (Price 1995). In the latter half of the century, however, Western nations foisted this normative restraint on the rest of the world when they stigmatized chemical weapons as "weapons of the weak" and the "poor man's bomb." According to Price, it made good military and geopolitical sense for Western states to pressure Third World nations to abandon chemical weapons stockpiles, because such weapons could pose a real, non-nuclear threat to Western military intervention $(1995,1997)$.

But, according to the argument, in order to make this norm credible, powerful nations like the U.S. had to forgo the use of chemical weapons, even in situations when their use would have been militarily advantageous (Price 1997). There is some evidence to this effect (see Table 1). First, the U.S. signed the Geneva Protocol in 1925, which prohibits nations from being the first to use chemical weapons in war, and later ratified the accord in $1975 .^{4}$ More recently, the United States ratified the Chemical Weapons Convention of 1993, which is a stronger treaty that requires nations to eliminate their chemical weapon stockpiles. Perhaps more importantly, the United States has not used chemical agents intended to directly kill enemy soldiers through asphyxiation or by causing chemical burns since World War I.

By looking more broadly at the U.S. history of toxic violence in order to draw out and examine political debates about what does and does not constitute a "chemical weapon," this paper builds on Price's analysis but also tells a more complicated story: one which indicates that even longstanding and broadly-shared humanitarian norms, such as that governing chemical weapons, do not strictly determine or entirely restrain the forms of violence the United States employs. The cases below demonstrate that herbicides and incapacitating gases used since 1961 by the United States - as methods of violence in wars and conflicts - could quite plausibly be considered chemical weapons by the definition of the Geneva Protocol of 1925, which sought to prohibit the use of "asphyxiating, poisonous, or other gases, and of all analogous liquids, materials, or devices." Archival evidence, for instance, shows that U.S. officials knew in advance that their use of herbicides to destroy foliage and food crops in hostile territories during the Vietnam War would be condemned as a form of chemical warfare, but chose to use the

\footnotetext{
${ }^{3}$ One objection to this argument might be the supposed risks that chemical weapons use might pose to friendly combatants, as frequently happened in World War I. However, this is not an inherent quality of chemical weapons because, with more advanced weaponry, they could be remotely delivered without fear of friendly exposure.

${ }^{4}$ Signing such an agreement does not, of course, make it legally binding without ratification. But it does signal an intent to ratify. At the very least, it is an acknowledgement made by U.S. officials of the existence of a global norm against chemical weapons.
} 
Table 1: U.S. Policy on Toxic Weapons

\begin{tabular}{ll}
\hline Year & Event \\
\hline 1925 & $\begin{array}{l}\text { U.S. government signs Geneva Protocol, which prohibits the first use } \\
\text { of "asphyxiating, poisonous or other gases, and of all analogous } \\
\text { liquids, materials or devices." }\end{array}$ \\
Refrains from using chemical weapons in World War II. \\
1941-1945 & Refrains from using chemical weapons in Korean War. \\
$1961-1971$ & $\begin{array}{l}\text { Uses large amounts of herbicides in Vietnam War as a defoliant and } \\
\text { to destroy food crops. }\end{array}$ \\
Uses large amounts of incapacitating gases in Vietnam, including \\
tear gas, enhanced tear gas, and nauseating agents. \\
Supports drug crop eradication with herbicides in-at various \\
times-Mexico, Burma, Pakistan, Guatemala, Panama, Belize, and \\
Columbia. \\
$\begin{array}{l}\text { Ratifies the Geneva Protocol. } \\
\text { Ratifies the Chemical Weapons Convention, which prohibits } \\
\text { chemical warfare and commits all signatory nations to destroy their } \\
\text { chemical weapons stockpiles. } \\
\text { incapacitants as prohibited weapons. }\end{array}$ \\
\hline
\end{tabular}

chemicals regardless. And when the Nixon Administration sought to formally interpret the Geneva Protocol as excluding herbicides and incapacitating gases, ${ }^{5}$ it was strongly rebuked by the United Nations General Assembly, which voted in an overwhelming majority to support a resolution that explicitly interprets the Protocol as prohibiting their use in war. ${ }^{6}$ Indeed, in 1975 , with the war in Vietnam winding down, the U.S. Congress ratified the Geneva Protocol with the explicit recognition that the treaty bars the use of herbicides and incapacitating gases in war ${ }^{7}$ (see Washington Post 1974). Even with this recognition, however, the United States has continued to

\footnotetext{
${ }^{5}$ The Nixon Administration was attempting to push Congress to ratify the Geneva Protocol as part of a larger strategy to strengthen the norm against immediately lethal chemical weapons in order to limit the military capacities of weaker nations, but still wanted to maintain its own ability to use herbicides and incapacitating gases in Vietnam and in future wars (see Smith 1969).

${ }^{6}$ The vote on the resolution was 80-3, in which the only dissenting votes came from the United States, its Australian ally also fighting in Vietnam, and Portugal, a country that had recently employed herbicides in its war to maintain control over its African colony of Angola (Baxter and Buergenthal 1970).

${ }^{7}$ The Chemical Weapons Convention of 1993, signed and ratified by the United States, also explicitly defines incapacitating gases used in war as banned chemical weapons.
} 
use herbicides as a method of violence in counter-insurgency campaigns in numerous countries across the world in its "War on Drugs."

What is, and what is not, a chemical weapon is therefore not as easy to determine as it might at first seem. Quite the contrary, the interpretation of whether or not a method of toxic violence should be declared a "chemical weapon" has much to do with politics and the structure of the world-system within which a national government acts. Nevertheless, as these cases make clear, whenever the United States has used toxic chemicals as a method of violence in overseas conflicts, it has faced both internal and external opposition and has been condemned for violating international humanitarian norms. In an effort to maintain the consent of critical constituenciesboth foreign and domestic - the United States has sought to legitimate this violence.

\section{Herbicides: Vietnam, 1961-1971}

From 1961 to 1971 the United States Air Force sprayed millions of gallons of herbicides over Vietnam and Laos, intending to defoliate vegetation to eliminate the cover it provided to enemy soldiers and to destroy "enemy" agricultural crops in hopes of creating food shortages (Buckingham 1982). From the start of this enterprise, the U.S. government was confronted with claims that it was using a chemical weapon. Indeed, some of these initial challenges came internally, when members of the Department of State counseled against using herbicides to destroy food crops. In one internal memo Edward Murrow (1962), the director of the U.S. Information Agency, privately warned that

chemical and biological warfare are subjects which arouse emotional reactions at least as intense as those aroused by nuclear warfare [...] No matter how reasonable our case may be [to utilize chemicals to destroy food crops]. I am convinced that we cannot persuade the world - particularly that large part of it which does not get enough to eat - that defoliation "is good for you."

Likewise, Secretary of State Dean Rusk (1962), wrote to the President that "the use of strange chemical agents, to destroy crops, strikes at something basic implanted in human beings (even if the people do not - as many will — fear that the chemical agents are also directly harmful to people)."

When the U.S. defoliation and crop destruction programs were made public, criticism became widespread. U.S. House of Representative member Robert Kastenmeier (1963), for instance, wrote a letter of protest to President Kennedy, decrying the use of herbicides, which he specifically called a chemical weapon. Public criticism of these weapons came not just from the U.S. student antiwar movement, but also from well-recognized and outspoken scientists of the era, who regularly petitioned the government and otherwise spoke out against the military's use of herbicides in Vietnam, also classifying them as chemical weapons (New York Times 1966a; O'Toole 1967; Reinhold 1969). In response to these challenges, U.S. governmental officials worked to legitimate their contested weapons.

Legitimating herbicides in Vietnam through defensive categorization. Through the technique of defensive categorization, officials deny that the military is using a condemned form of violence. They attempt to make such denials convincing by stressing how different a contested form of violence is compared to other types of violence that are universally reviled and deemed 
impermissible. In the case of herbicides, officials sought to do this by claiming that the chemicals used in Vietnam were the same as those widely used for agricultural and industrial purposes around the world and therefore, it was implied, could not possibly be considered chemical weapons.

For instance, when the Chiefs of Staff presented their proposal to President Kennedy to use herbicides for defoliation and crop destruction in Vietnam, asking for his approval, they were already practicing defensive categorization by claiming that the chemicals are "commercially produced in this country and have been used for years in industrial and agricultural plant growth clearance operations" (Gilpatrick 1961). Similarly, in preparation to legitimate the use of herbicides in war, a memo was sent out to instruct U.S. embassies on how to deal with press inquiries regarding defoliation. In the memo, the Department of State (1961) advised officials to tell reporters that the "operation involves use of material which are similar to those used everyday for clearing rights of way in the United States. As our people know from experience, these defoliants of the 2-4D variety [including Agent Orange] are not harmful to humans, animals, or the soil."

This rhetorical strategy would continue to be used throughout the war. One example of defensive categorization comes from a 1965 New York Times article, which reads, "officials describe the crop destruction chemical as a commercial weed killer, identical with a popular brand that many Americans spray on their lawns. It is not poisonous, and officials say that any food that survives its deadening touch will not be toxic or unpalatable" (Mohr 1965). Another example comes from a press conference held in 1968, in which U.S. officials told reporters, "no chemical is in use here that has not been thoroughly tested and available on the American domestic market. [Officials] said that one of the agents sprayed from planes over Vietcong areas is a chemical popularly used to fight crabgrass in America" (Lescazee 1968).

The logic of defensive categorization requires a very narrow interpretation of what constitutes a prohibited form of violence. In the case of chemical weapons, such a narrow interpretation means that a chemical weapon, in order to be defined as such, must cause direct, immediate, and intentional harm through exposure. The logic that U.S. officials were relying on in their practice of defensive categorization was made explicit in a letter sent by the Kennedy Administration in response to Representative Kastenmeier's letter, which had - as mentioned above - accused the U.S. government of using chemical weapons in Vietnam. In reply, Assistant Secretary of Defense William Bundy (1963) wrote that, "in the Republic of Vietnam, the use of chemical and biological weapons has not occurred, and the compromise of moral principles has not been an issue." This was true, he explained, because,

As you are aware, chemical warfare as defined by international law requires injury to the physical person of the enemy. The chemicals that have been used are weed-killers of the same types... used-especially by farmers-in the United States and other countries. They are commercially available in the United States and many other countries. They are not injurious to man, animals, or the soil.

Despite such claims, there are many reasons why herbicides - as used by the United States in the war in Vietnam - could be considered chemical weapons. Certainly, they were used for their chemical toxicity and could reasonably be considered "poisonous or other gases" banned by the Geneva Protocol of 1925. The actual text of the document does not include, after all, a stipulation that in order to be considered a prohibited chemical weapon, a toxic weapon used in 
war must cause direct harm to a person and could not be a commercially available product, despite the Kennedy Administration's interpretation of the treaty.

Regardless, while it is now known that these herbicides produced tremendous physical harm to successive generations of people in Vietnam, due to their carcinogenic and teratogenic effects, this was not common knowledge at the time. ${ }^{8}$ But Kennedy Administration officials must have known that destroying food crops with chemicals - in effect creating hunger and potentially killing persons through starvation - was causing a kind of "injury to the physical person of the enemy," and to civilians alike. ${ }^{9}$ In this sense, using herbicides to destroy food crops could constitute the use of a chemical weapon even by the Kennedy Administration's own narrow interpretation. But such logic undermines the practice of defensive categorization, and was therefore suppressed and certainly not made part of an official discourse.

Historical records indicate that defensive categorization was a primary means by which the United States sought to legitimate its use of herbicides in Southeast Asia. But it was far from the only legitimating technique U.S. officials used. They also employed a method of surrogacy.

Legitimating herbicides in Vietnam through surrogacy. Through the legitimating strategy of surrogacy, the U.S. government directs other nations or armed groups to utilize weapons or violent practices that may breach international humanitarian norms as a means of cloaking its own culpability (Bonds 2012). U.S. officials elected to utilize this legitimating method when they first decided not to conduct herbicidal crop destruction missions directly, but to, instead, provision the Republic of Vietnam's military with the equipment and technical knowledge necessary to carry them out. A memo from the Department of Defense to President Kennedy, for instance, stated, "American participation would be as unobtrusive as possible and limited to technical advice and assistance" (McNamara 1962). So, while the first crop destruction missions utilized U.S. supplied helicopters, herbicides, spray equipment, and technical advice, they were conducted by Southern Vietnamese pilots and soldiers (Joint Chiefs 1963).

Direct surrogacy, however, was not a long-term practice in that, by 1964, the U.S. government began carrying out crop destruction missions in Vietnam and Laos itself because its fixed-winged aircraft could spray greater areas, had a longer range, and were not as vulnerable to enemy small-arms fire compared to the U.S.-supplied Vietnamese helicopters (Buckingham 1982). Regardless, officials misleadingly claimed, up until 1965, that U.S. aircraft were not involved in any crop destruction missions (Raymond 1965). ${ }^{10}$ But U.S. officials did not only attempt to use strategies of defensive categorization and surrogacy to legitimate the use of herbicides in Vietnam, they also employed a humanitizing discourse.

\footnotetext{
${ }^{8}$ The major manufacturers of 2,4,5-T, which is the major component of Agent Orange and other herbicides used by the government in Vietnam, were aware of the presence of dioxins in this widely-used herbicide, but they did not disclose this information to the public. While Dow Chemical claimed, in its legal defense against a lawsuit filed by Vietnam War veterans, that it told Secretary of Defense McNamara about dioxin contamination in 1965, this remains unsubstantiated (Chicago Tribune 1983).

${ }^{9}$ Members of the Kennedy Administration knew, for example, that the first major crop destruction campaign had, by the military's estimate, destroyed enough rice to feed 1,000 people for an entire year (Joint Chiefs 1963).

${ }^{10}$ U.S. crop destruction missions were, to some extent, an open secret by 1965 (Mohr 1965). But it was not until 1966 that the U.S. government took responsibility for the program, when it released an official statem ent in response to the hunger strike of a landscape architect living in New York, who demanded in his protest that the government inform the public about its crop destruction campaigns (New York Times 1966b).
} 
The use of humanitizing discourse to legitimate herbicides in the Vietnam War. Through the use of humanitizing discourse, U.S. officials may attempt to legitimate contested forms of violence by emphasizing the care taken to avoid civilian harms. This tactic was often used during the Vietnam War, where U.S. officials regularly stressed how careful military planners were to avoid directly spraying civilians or their crops. Numerous examples can be cited. For instance, a news reporter for the New York Times wrote in 1965, "officials say that elaborate pains are taken to prevent defoliants from falling on areas inhabited by friendly civilians" (Beecher 1965). An article the following year stated, "the key to the defoliation question is discrimination. If the weapon is used discriminately, it can be effective. At least this is the official appraisal here of the strictly technical aspects of the United States' defoliation program [...] Defoliation is carefully controlled" (Oka 1966). Officials also repeatedly stressed that care was taken to ensure that herbicides were only used to destroy food crops in areas "known to be used to produce food for Vietcong military units" (Mohr 1965). For instance, a question and answer sheet distributed by the State Department to advise U.S. embassies around the world on how, among other things, to speak about the military's use of herbicides included this hypothetical exchange:

QUESTION: How can you justify the deliberate destruction of rice fields and other crops by herbicide spraying? Isn't this taking food from the mouths of poor farmers and their families, and gaining nothing but hostility?

ANSWER: The destruction of rice fields and other crops impedes the Viet Cong. Crop destruction has taken place only in areas fully controlled by the Viet Cong for a considerable period of time. There the harvested foodstuffs, used solely by the Viet Cong, sustain the attackers in their military operations and their acts of terrorism against innocent civilians (USIA 1967: 18).

Later attempts were made to convince the public that civilians were not harmed by the use of herbicides to destroy food crops because, officials stressed, the U.S. only targeted cultivated lands in "remote" areas. For example, an article from the New York Times states that crop destruction campaigns "are targeted on pockets of land cultivated by enemy troops in the largely unpopulated areas of central Vietnam. No food denial mission has been flown in an area with a government-registered population of more than 20 people per square mile, the officials said" (Lescaze 1968).

The humanitizing discourse used by U.S. officials, however, was not an accurate reflection of real world events. Geographical estimates since the War-using archived flight records of spray missions - contradicted claims that U.S. officials exercised a great deal of caution to avoid spraying civilians (Stellman et al. 2003). Quite the contrary: records show that 3,181 hamlets were directly sprayed. Based on military estimates of the populations of these communities, a minimum of 2.1 million persons were under U.S. planes that were showering down Agent Orange and other herbicides ${ }^{11}$ (Stellman et al. 2003). Further contradicting claims of care and discretion to avoid civilian harm, studies commissioned by the U.S. military itself during the Vietnam War found that herbicidal crop destruction campaigns largely affected civilian farmers (Bretts and Denton 1967). Internally, despite the military's humanitizing

\footnotetext{
${ }^{11}$ This estimate does not include the hundreds of thousands of people who were directly sprayed while traveling along roads, working in fields, or otherwise outside their communities but still underneath U.S. planes.
} 
discourse, officials acknowledged that "available evidence indicates that the civilian population in VC [Vietcong] controlled areas bears the brunt of these operations" (Warren 1968: 27). So, taken together, defensive categorization, surrogacy, and the use of a humanitizing discourse were all used to legitimate the military's use of herbicides in Vietnam and Laos. Many of these same tactics, as we will see, were also used to legitimate the use of incapacitating gases used in the War.

\section{Incapacitating Gases: Vietnam 1965-1972}

The Johnson Administration was taken by surprise by the international and domestic controversy created after the U.S. military attacked villages in the Boi Loi Woods in Vietnam in an attempt to defeat enemy soldiers and push civilians into "strategic hamlets," or government controlled refugee camps. U.S. jets first bombed the area, then sprayed surrounding forests and rubber plantations with herbicides, and then inundated the area with napalm and incendiary bombs in an ultimately unsuccessful attempt to create a self-sustaining forest fire that would destroy any tree that could provide enemy cover (Buckingham 1982). The uproar created by this military campaign did not, surprisingly, focus on the U.S. military's campaign of near total destruction in the Boi Loi Woods. Rather, the controversy focused more specifically on the U.S.'s use of tear gases and other incapacitating agents on civilians to force them from their homes and villages in the midst of the bombardment.

The Johnson Administration quickly learned that the use of incapacitating gases would be decried as the use of a chemical weapon. The New York Times, for instance, reported that this was the, "first time the U.S. has used gas in warfare since WWI" (Frankel 1965). Internationally, the United States faced immediate criticism from members of Britain's governing Labor Party, which had otherwise been an important international supporter of the U.S. war in Vietnam (Bruce 1965). Domestically, democratic Senator Frank Morse told reporters that the tactic was "justly condemned by the general opinion of the civilized world" (Frankel 1965). U.S. Senator Mike Mansfield, a powerful democratic ally in the Senate, made a more quiet protest in the form of a letter to the President, questioning whether the use of incapacitating gases may do more harm to the U.S. in regard to international opinion than any military advantages it could give in Vietnam (Johnson 1965). And the U.S. government would face enduring opposition from the scientists and scientific organizations advocating against the use of herbicides in Vietnam, who were just as opposed to the use of incapacitating gases, which they also condemned as a type of chemical weapon (see O'Toole 1969).

Though these gases were themselves nonlethal, they were primarily used by the U.S. military as a means of forcing suspected enemies out of bunkers, trenches, and other protected areas so they could be more easily killed by conventional weaponry. Used as such, the U.S. government determined that these gases were a very important military tool that it would continue to use, despite international and domestic condemnation (Bundy 1965). But in doing so, U.S. officials sought to obscure the gap between humanitarian norms and actual military policy.

Legitimating incapacitating gases through defensive categorization. Through defensive categorization, officials claimed that such gases were simply "riot control gases" or tear gases commonly used by police around the world, and therefore could not plausibly be considered chemical weapons. For instance, when President Johnson met with the UK Foreign Secretary in an attempt to dampen the international uproar after the U.S. military sprayed incapacitating gases 
on civilians in the Boi Loi Woods, he claimed that "the gas was one in common use by our own police forces, was frequently employed for quelling riots, and was stocked by many countries" (Bruce 1965). Likewise, Secretary of State Rusk gave a press conference after the Boi Loi Woods attack, in which he stated,

The shadow of gas warfare has been raised in connection with these incidents. That is not involved. We are not embarking upon gas warfare in Viet-Nam... We are not talking about gas that is prohibited by the Geneva Convention of 1925, or any other understandings about the use of gas. We are talking about a gas which has been commonly adopted by the police forces of the world as riot control agents - gases that are available commercially, and have been used on many occasions, some in this country; and on many occasions in other countries.

U.S. officials would use this rhetorical strategy in successive years, and indeed throughout the war, to legitimate the use of incapacitating gases (USIA 1965).

For instance, a question-and-answer sheet put out by the U.S. Information Agency, created to help U.S. embassies around the world prepare for press inquiries, includes this hypothetical dialogue:

QUESTION: Why do you use poison gas against the other side? Don't you adhere to the Geneva Conventions which prohibit this kind of warfare?

ANSWER: Neither the RVN [Republic of Vietnam] nor any of its allies has used poison gas... Tear gas is a nontoxic agent which police forces use for riot control in almost every country of the world as a means of limiting violence and casualties... Its use is not contrary to any Geneva Convention (USIA 1967: 19).

As the examples above demonstrate, the Johnson Administration, and later the Nixon Administration, consistently sought to legitimate incapacitating gases by claiming that they were commercially available and widely used for law-enforcement purposes, and therefore should not be considered a type of weapon banned by the Geneva Protocol of 1925. There are inconsistencies, however, with such claims-making. First, the actual context in Vietnam was very different than that to which it was being compared: the U.S. was not using tear gas in police actions but in military campaigns where it was simultaneously dropping bombs and firing bullets. Second, the scale was very different between police use of tear gas, which implies infrequent and sporadic use, and the regular and sustained use of incapacitants by the U.S. military in Vietnam, which regularly deployed them by helicopter, high powered fans, and through shells and bombs. ${ }^{12}$ Finally, while the U.S. regularly claimed that these incapacitant gases were the same tear gases used by police around the world, officials later acknowledged that much of the gas used by the military was a "super" tear gas created to last longer in the environment and was not actually used by police (Committee on Foreign Relations 1971). Furthermore, U.S. forces also, at least initially in the war, often added a nauseating agent that could induce vomiting for up to two hours after contact (Frankel 1965; Margolis 1965). Archival evidence further shows that the Johnson Administration knew as early as 1965 that the tear gases

\footnotetext{
12 The U.S. military itself estimated that it had purchased and transported more than 13,000,000 pounds of incapacitant gases for use in Southeast Asia between 1964 and 1969. A Harvard biologist at the time estimated that this was enough gas to effectively cover 80,000 square miles (Wilson 1969).
} 
used in Vietnam and those used in domestic police work were very different (Horning 1965), but Administration officials nevertheless practiced defensive categorization by claiming that the two were one and the same.

These above inconsistencies cast doubt about U.S. claims that its use of incapacitant-type gases should not be considered a type of chemical warfare banned by the Geneva Protocol. The text of the Protocol and the context in which it was written raise further misgivings. After all, the Protocol seeks to ban "asphyxiating" gases, and tear gases certainly seem to fall into this category because they induce coughing and make breathing more difficult. And while the U.S. hoped to promote a narrow definition of the Geneva Protocol as banning only lethal chemicals, the drafters of the Protocol never made such a specification and likely had non-lethal incapacitants in mind. They were, after all, the first chemical gases used in World War One and constituted up to a tenth of all chemical agents used throughout the war (Coleman 2005). Despite these inconsistencies, defensive categorization was likely an effective tool used to legitimate toxic violence in the Vietnam War, as was the use of a humanitizing discourse.

The use of humanitizing discourse to legitimate incapacitating gases in Vietnam. U.S. officials also regularly sought to defend the use of incapacitating gases in Vietnam with a humanitizing discourse, which did not stress so much the care taken to avoid civilian exposure, as with herbicides, but instead stressed that the use of this contested weapon may have humanitarian benefits. This rhetorical strategy is well expressed in a 1965 New York Times article that reads, "US officials claimed gassing the village was more humane than bombing it or sending in a barrage of artillery" (Frankel 1965). Throughout the War, officials - including President Johnson - argued that the use of incapacitating gas was "authorized in an effort to save lives" (Johnson 1965) and that the gas did little harm to persons, having "only a temporary effect" (Committee on Foreign Relations 1971) of "nausea, choking, and copious weeping" (Washington Post 1972). According to this humanitizing discourse, "these riot control agents frequently make it possible to capture enemy soldiers unharmed and are particularly useful in reducing civilian casualties when the enemy has infiltrated into populations centers or built-up areas or is believed to be holding civilian hostages" (official quoted in The New York Times 1969).

Despite these claims, the historical record indicates that incapacitating gases were not primarily used to achieve humanitarian goals, but were used because they increased the capacity of the U.S. military to kill suspected enemies. A former official in the Johnson Administration, George Bunn, who participated in constructing the humanitarian rationale for the use of incapacitants later acknowledged this in Congressional testimony. He stated that "the humanitarian justification given to the United Nations was not observed in practice... From saving civilian and enemy lives - tear gas had become simply a better killer-at least in some of its uses" (Committee on Foreign Relations 1971: 54). This same point was made much earlier, in 1965, by a former administration official who complained to The New York Times (1965) that "the American use of tear gas in Vietnam does not match the humanitarian justification for its use given by the government." The former official was further quoted as saying, "large numbers of tear gas grenades have been dropped on Vietcong strongholds from helicopters that were followed by B-52s dropping explosive or anti-personnel-fragmentation bombs" (The New York Times 1965). In other words, the United States was not using incapacitants to save lives. It was using them, much like in World War I, to push soldiers out of protected positions so they could be more easily killed and their positions could be overtaken using more conventional weapons. 
The United States, after all, was dropping 270-pound bombs, grenades, and artillery shells filled with incapacitants along with, not instead of, lethal weapons. The previously discussed 1965 incident at the Boi Loi Woods is a case in point. While the United States sprayed tear gas and nauseating gases into hamlets, it did this within a context of aerial bombardment using napalm and cluster bombs (Buckingham 1982).

\section{Herbicides: International "War on Drugs," 1970-Present}

The aerial eradication of drug crops, accomplished by spraying herbicides from fixed-wing aircraft and helicopters in foreign countries, has been a longstanding component of U.S. foreign policy (Buxton 2006). The history of this policy dates back to the Nixon Administration, which provided helicopters, herbicides, and technical assistance in 1970 to the Mexican government to destroy marijuana and poppy fields (The New York Times 1970). Since that time, the United States has provided support for, or actually operated, anti-drug herbicidal campaigns in Burma, Guatemala, Panama, Belize, and Pakistan (Courier-Mail 1988). The United States also began providing major support in 2000 for drug eradication in Colombia through a multi-billion dollar military aid package to support the government's drug suppression and counter-insurgency efforts known as "Plan Colombia." Today the United States continues to fund the private company DynCorp to conduct aerial drug crop eradication in Colombia. ${ }^{13}$

While the United States' long-standing policy regarding the use of herbicidal chemicals during the "War on Drugs" has not been widely criticized as a violation of international normative commitments regarding chemical weapons, the case below makes clear that it certainly is a form of toxic violence and has been strongly criticized by international human rights organizations (Robberson 2001), peace and environmental NGOs (Earthjustice 2002; Witness for Peace 2002), and has been treated with some suspicion and criticism by the U.S. Congress (Pauker 2003). As such, U.S. officials have worked to legitimate the use of herbicides as a weapon in the "War on Drugs" in familiar ways.

Legitimating herbicides for drug eradication through defensive categorization. U.S. officials have sought to legitimate the use of herbicides in the "War on Drugs" as if they were simply chemical tools used for conventional agricultural purposes, stating for instance "that the coca spraying is being carried out in accordance with regulatory controls required by the Environmental Protection Agency as labeled for use in the United States" (State Department 2002; see also State Department 2006). However, their use in these circumstances is better defined as that of a toxic weapon.

That herbicides used to destroy drug crops are a kind of weapon, and not simply an agricultural tool, is made clearer when examining the broader context in which they are used: often in the midst of wars, counter-insurgency campaigns, or other social conflicts. In particular, there has been no clear defining line between U.S. anti-drug policies and counter-insurgency foreign policy in the U.S.-backed drug eradication programs of Mexico, Burma (now Myanmar), and Colombia (Buxton 2006). Revolutions and armed rebellions, after all, require the provision of weapons. In the absence of superpower patrons, revolutionaries may look to use "highly lootable" resources for funding, such as drug crops (Le Billon 2001). Or, on the other hand, the

\footnotetext{
${ }^{13}$ More than three million acres in Colombia have been sprayed with herbicides since Plan Colombia was put into effect (EarthJustice 2011). Colombia's Council for Human Rights and Displacement estimates that aerial fumigation displaced more than 70,000 people in the first two years of spraying alone (Dion and Russler 2008).
} 
capacity to grow and profit from drugs crops may create conditions in which organizations arm themselves and fight battles in order to protect their illicit source of wealth (Le Billon 2001). In either case, efforts to eradicate drug crops are not simply counter-drug tactics, but as a matter of intention or as a matter of effect, are also military campaigns in larger armed conflicts. In the context of the "War on Drugs," herbicides have been used as a weapon in the sense that they are an implement of force used against the will of and despite the resistance of others. Paying further attention to U.S.-backed drug eradication in Colombia makes this point clear.

U.S.-backed drug eradication campaigns in Colombia since the 1990 s occurred during a period in which the nation's government was engaged in a full-scale counter-insurgency war, in which its main adversaries were communist rebel forces that were profiting from drug production and trafficking (GAO 2008). It was in this context that the United States spent \$4.9 billion dollars on "Plan Colombia" between 2000-2006 in order to provide "the Colombian military and National Police with a range of capabilities, primarily air mobility, needed to pursue Plan Colombia's counternarcotics and security objectives" (GAO 2008: 5). This "air mobility" came primarily in the form of the increased capacity to destroy drug crops with herbicides from above. The communist forces in Colombia consequently sought to protect drug crops from destruction by attempting to take down spray planes. As a result, efforts to destroy drug crops from the air in Colombia resembled military strikes much more than they resembled more conventional agricultural uses of herbicides, as the below quote from a U.S. Congressional report describes:

A typical spray mission consists of four spray aircraft supported by helicopter gunships to protect the spray aircraft along with a search and rescue helicopter to rescue downed pilots and crew. In addition, ground security is provided as needed by the Army Counternarcotics Brigade. (GAO 2008: 39)

Because herbicides in the "War on Drugs" were used as a kind of weapon in violent conflicts, their human health impacts are likely much more extensive than when used in conventional agriculture. For instance, the U.S. State Department practices defensive categorization by asserting that its use of the herbicide glyphosate in Colombia, which is the active ingredient in the commercially available herbicide "Round-Up"," is consistent with its commercial use in the United States. However, such a comparison ignores an additional chemical agent called "cosmo-flux" that makes the herbicide more effective, but is not domestically available in stores (EPA 2002). Moreover, higher concentrations of glyphosate are used in Colombian drug eradication than are allowed in U.S. agriculture (Pauker 2003). And because the aircraft deploying herbicides often come under enemy fire, they fly at higher altitudes and faster speeds than they would fly when "crop dusting" in the United States, increasing the extent of herbicidal drift and other unintended applications of herbicides that contaminate water and destroy plants in adjacent legal cropland, forests, and wetlands (Pauker 2003). Beyond defensive categorization, the U.S. has used a humanitizing discourse to legitimate its toxic weaponry used in the "War on Drugs."

The use of humanitizing discourse in drug eradication campaigns. In order to convince critics that its herbicide campaign in Colombia was not adversely affecting civilians, the State Department required the government of Colombia to "compensate growers for legal crops sprayed in error" (State Department 2003). This presumably would be quite common because the 
planes applying herbicides in Colombia move at a much faster speed and at a much higher altitude than planes would fly under normal agricultural circumstances, in order to avoid being shot down by enemy fire (EPA 2002). Press (Forero 2001) and NGO accounts (Earth Justice 2002; Witness for Peace 2002), as well as the findings of the government of Columbia's Human Rights Ombudsman (Robberson 2001), attest to the frequency of this problem.

The U.S.-instituted program, however, appears to be more hollow rhetoric than an actual plan to compensate people for their losses due to errant herbicides. According to the U.S. State Department in 2003, the government of Colombia had received 4,329 complaints of legal crops wrongly destroyed by the aerial application of herbicides. The Colombian government claimed it investigated 2,745 of these cases and found that all but five were fraudulent (State Department 2003). The situation in 2007 was no better; after having received a total of 6,778 complaints since the program's inception, the government of Colombia denied compensation to all but 43 . The government of Colombia determined that the several thousand other cases are "false" claims, in which growers of coca plants have allegedly sought compensation for their destroyed drug crops (State Department 2003, 2007). It must be taken into account, however, that the government of Colombia is regularly rated poorly in terms of corruption and has often been accused of committing human rights abuses against its citizens (Livingston 2004). Taken in this context, this U.S.-required program, undertaken by the Colombian Government, is a humanitizing discourse used in hopes of satisfying critics, even if it has not actually rectified human rights abuses committed through the destruction of legal crops through the aerial application of herbicides.

Surrogacy and herbicides in drug eradication campaigns. Through surrogacy, the United States implements policies that violate international humanitarian norms, but it does so in such a way to create the impression that other national governments are ultimately responsible. This is despite the fact that the United States may fund such campaigns and provide the technical means to carry them out. For instance, by 1980, the U.S. government had provided Mexico a total of 70 million dollars in equipment and technical assistance, including spray equipment, 41 helicopters, and 22 spotter planes to conduct aerial drug eradication campaigns (Riding 1980). The United States continued providing the Mexican government herbicides, aircraft, and funding throughout the $1980 \mathrm{~s}$, and eventually even supplied pilots to conduct aerial missions to destroy illegal crops. Under Plan Colombia, the United States also provided substantial support for drug eradication. According to the U.S. Government Accountability Office (2008: 39), the United States has provided hundreds of millions of dollars in support for drug fumigation in the form of "U.S.-owned spray aircraft and helicopters, as well as contractor support to help fly, maintain, and operate these assets at forward operating locations throughout Colombia."

The United States, through surrogacy, can distance itself and maintain plausible deniability of human rights violations that occur through such campaigns, even if they were only begrudgingly accepted by host countries. Mexico, for instance, initially refused U.S. proposals for herbicidal drug eradication in the $1970 \mathrm{~s}$, and only submitted to them after the United States instituted an economically crippling border blockade (Onis 1969; Buxton 2006). Colombia, while undertaking some U.S.-supported herbicidal drug eradication in the $1990 \mathrm{~s}$, initially refused U.S. plans to dramatically increase fumigation. The country's leaders buckled to U.S. pressure, however, after Colombia was placed on a list of non-cooperating countries in the drug war, which affected the nation's ability to receive international loans and other forms of assistance 
(Buxton 2006). Surrogacy, then, is another important means by which U.S. officials have sought to legitimate toxic violence in the "War on Drugs."

\section{Legitimation and the Contradictions of Hegemony}

Hegemony does not simply mean military and economic dominance. Rather, it means that a hegemon must exert its influence over the world-system through some combination of coercion and consent (Arrighi and Silver 1999). The cases in this article contribute to our understanding of hegemony by demonstrating that these two forms of power do not only complement one another, but that they are also potentially contradictory. On the one hand, the United States has sought to exert global moral leadership by proclaiming the "rights of the people" and by promising a liberal reformative program toward their full provision (Wallerstein 1995). Even in times of war, the United States has experienced pressure to comply with international norms that outlaw and stigmatize certain acts of violence that are identified as especially cruel or harmful to civilians. On the other hand, the United States has regularly used military violence across the globe throughout its tenure as hegemon in order to maintain its leading position within a system of global inequalities that can only be maintained through coercive force. The question is, then: which is most fundamental to hegemony, coercion or consent, when the two seem at odds with one another?

This already difficult question is complicated further when we account for the fact that powerful nations are not only passive recipients of global political culture, but are also active cocreators of global norms. An additional question here, then, is whether, after having coconstructed a global norm as a means of controlling the military power of weaker nations - as in the case of landmines, nuclear weapons, or chemical weapons - a hegemonic power will itself be pressured to comply. Social constructionist theorists in international relations have argued for the affirmative (Price 1997; Tannenwald 2007; Sikkink 2011). More critical scholars of humanitarian arms control efforts are likely to disagree (see Cooper 2011; Stavrianakis 2011). The cases here, however, show some evidence in support of both positions, though in the end a hegemonic power's need to utilize militarily effective power likely trumps its need to exercise cultural leadership, which might be diminished by violating long-standing and widely-shared humanitarian norms.

The examination of U.S. policy on toxic violence demonstrates that, on one hand, the United States has complied with the global ban on chemical weapons by abdicating the use of immediately lethal gases, even in situations when their use may have been militarily effective (Price 1997). It was likely in the hegemonic interest of the United States to abandon such weapons because, since 1969, it has undertaken efforts - along with other powerful nations - to strengthen the "chemical weapons taboo" and stigmatize them as "weapons of the weak" in order promote the more conventional military power of nations in the global North (Price 1997). On the other hand, however, the United States has not strictly complied with the ban on chemical weapons. Rather, it has regularly used toxic violence - albeit utilizing types of chemicals that are not immediately lethal - to achieve geopolitical goals since 1961 .

The fact that, when doing so, the United States has sought to either hide or exempt its own use of toxic violence from the chemical weapons ban is significant. It means that, while a hegemon's ability to utilize coercive violence may be of ultimate importance, its need to attain the consent of the governed in global affairs does not go away. These cases demonstrate that the 
United States has consistently used three main techniques to legitimate its use of toxic violence. Through the strategy of defensive categorization, U.S. officials claim that the military's use of a contested form of violence is very different from the kinds of violence that have been prohibited through international treaty-making. To make this case, they work to normalize this violence by stressing its routine and commonplace nature. U.S. officials also seek to legitimate contested forms of violence by using a humanitizing discourse, through which they either stress the care taken to avoid harm or argue that, in fact, the use of a controversial form of violence has humanitarian benefits. Through surrogacy, the U.S. government denies responsibility for the results of contested forms of violence used by client states, even if U.S. officials provided the resources and direction to carry it out. It is through these legitimating mechanisms that U.S. officials have sought to manage the contradictions of hegemony, in order to obscure the difference between professed appreciation of liberal or humanitarian norms and the violent military practices used to maintain a starkly unequal world.

Other researchers studying the legitimation of state violence might find the interpretive categories introduced here useful, as this brief application to the U.S. "War on Terror" shows. For one, U.S. officials certainly practiced defensive categorization in response to domestic and international criticism that the nation was using torture as a method of gathering intelligence. "The U.S. does not torture" proclaimed President Bush (2005), while other officials stressed the supposedly routine and commonplace nature of the "enhanced interrogations" used by the United States (Rejali 2007). And the United States and its allies have relied upon a humanitizing discourse to justify its military occupations in other nations during the "War on Terror" (Bricmont 2006). In Iraq, after no chemical weapons were found, the war was justified as being fought to bring democracy to the people of Iraq and to protect them from a ruthless tyrant. And the war and occupation in Afghanistan has been legitimated in terms of furthering women's rights. Likewise, despite evidence that the U.S. use of drones to carry out targeted assassinations has resulted in hundreds of civilian deaths (Woods and Lamb 2012; Ackerman 2013), U.S. officials continue to legitimate this violence by stressing the "precision" of these weapons and the "care" taken to avoid harming non-target persons (see Brennan 2012).

Finally, the United States has used the technique of surrogacy as a legitimating tool as well during the "War on Terror." For instance, leaked diplomatic cables between the Yemeni government and the United States reveal that Yemeni officials were willingly claiming responsibility for missiles fired into the country by the U.S. aimed at insurgent groups (Amnesty International 2010). This was certainly in the interest of the Yemeni government, which did not have to disclose to its citizens that the United States was directly attacking rebels within its borders and infringing on Yemeni sovereignty. This was also in the interest of the United States when, for instance, in one 2009 attack, it did not have to take responsibility for the cluster bombs that killed 41 civilians, including 21 children (Amnesty International 2010). Of course, researchers studying the legitimation of violence outside a U.S. context may also find this typology useful, because practically all states, to a greater or lesser degree, work to secure geopolitical interests using military violence that is not entirely consistent with global humanitarian norms. These states, too, might utilize the techniques of defensive categorization, humanitizing discourse, and surrogacy in hopes of distancing themselves from, justifying, or explaining away stigmatized forms of violence.

In conclusion, it is important to note that there is general agreement among worldsystems researchers that U.S. hegemony is expiring, if not already expired years ago. What this means in terms of U.S. military violence is far from certain. On one hand, it might mean that the 
United States will increasingly institute policies of "adjustment and accommodation" to other rising economic and political powers (Arrighi 2010). In such a situation, the U.S. government may be less likely to use egregious forms of violence in order to secure political and economic goals. This may be especially so in the wake of the "human rights revolution" of the past thirty years (see, for instance, Risse et al. 1999). Indeed, there is some evidence of increasing U.S. compliance with global norms over the course of time in U.S. toxic violence policy. While at the height of its economic and political power, the United States used toxic weapons at an incredible scale during the Vietnam War, showering herbicides across entire landscapes in an attempt to destroy whole forests and to poison crops that fed hundreds of thousands, while also using enormous quantities of incapacitating gases to increase the lethality of artillery and aerial bombardment campaigns. It is hard to imagine the United States using toxic violence on this scale at the current historical moment. And while the United States continues to fund the aerial fumigation of drug crops in Colombia, this use of toxic violence also seems to be waning. For instance, while the U.S. government sought to instigate a program of aerial fumigation to destroy poppy crops in Afghanistan used to make opium, it eventually had to abandon its plan due to strong opposition from the national government of Afghanistan and the United States' NATO allies $^{14}$ (Landay 2007).

Rather than instituting a program of "adjustment and accommodation," however, another possibility is that the U.S. will instead attempt to re-impose its will on the world-system primarily through its military might, regardless of its flagging economy (Wallerstein 2003; Arrighi 2010). In such a situation, compliance with international humanitarian norms would likely be cast aside if they interfered with the United States' ability to utilize militarily effective violence. While this study of U.S. chemical weapons policy provides no evidence indicating that such a situation is likely in the near future, other world events suggest that it remains a distinct possibility. Under such circumstances, we should expect U.S. officials to use many of the same legitimating techniques identified here.

\footnotetext{
${ }^{14}$ The United States instead carried out a program of manual poppy eradication, which it ceased in 2009 . This work
} has been carried forward by the United Kingdom and the Government of Afghanistan (Farmer 2009). 


\section{References}

Ackerman, Spencer. 2013. "Senator Lists the Death Toll From U.S. Drones at 4,700 People." Wired Magazine, February 12. Retrieved February 21, 2013 (http://www.wired.com/dangerroom/2013/02/graham-drones/).

Amnesty International. 2010. "Wikileaks Cable Corroborates Evidence of U.S. Airstrikes in Yemen." Retrieved April 3, 2011 (www.amnesty.org/en/news-and-updates/wikileakscable-corroborates-evidence-us-airstrikes-yemen-2010-12-01).

Arrighi, Giovanni. 2010. The Long Twentieth Century: Money, Power, and the Origins of Our Times. $2^{\text {nd }}$ Edition. Verso: London.

Arrighi, Giovanni and Beverly J. Silver. 1999. Chaos and Governance in the Modern WorldSystem. Minneapolis: University of Minnesota Press.

Baxter, R.R. and Thomas Buergenthal. 1970. "Legal Aspects of the Geneva Protocol of 1925." The American Journal of International Law 64: 853-879.

Beecher, William. 1965. "U.S. Will Step up Defoliation Missions in Vietnam." New York Times, September 10. (ProQuest Historical Newspapers).

Beier, J. Marshal. 2011. "Dangerous Terrain: Re-Reading the Landmines Ban Through the Social Worlds of the RMA." Contemporary Security Policy 32: 159-179.

Blau, Judith and Alberto Moncado. 2005. Human Rights: Beyond the Liberal Vision. New York: Rowman \& Littlefield Publishers.

Bonds, Eric. 2012. "Indirect Torture and the U.S. War on Terror: Surrogacy and the Legitimation of Contested Violence." Societies Without Borders: The Journal of Human Rights and the Social Sciences 7: 264-294.

Brennan, John. 2012. "The Ethics and Efficacy of the President's Counterterrorism Strategy." Speech delivered at the Woodrow Wilson International Center for Scholars, April 30. Retrieved February 26, 2013 (http://www.lawfareblog.com/2012/04/brennanspeech/).

Bretts, Russel and Frank Denton. 1967. An Evaluation of Chemical Crop Destruction in Vietnam. Rand Corporation, prepared for the US Department of Defense. Alvin L. Young Collection on Agent Orange.

Bricmont, Jean. 2006. Humanitarian Imperialism: Using Human Rights to Sell War. New York: Monthly Review Press.

Bruce, David. 1965. "Diary Entry by the Ambassador to the United Kingdom (Bruce)," March 23. Foreign Relations of the United States, 1964-1968. Document 211.

Buckingham, William A. Jr. 1982. Operation Ranch Hand: The Air Force and Use of Herbicides in Southeast Asia 1961-1971. Office of Air Force History. Alvin L. Young Collection on Agent Orange.

Bundy, McGeorge. 1965. "Memorandum From the President's Special Assistant for National Security Affairs (Bundy) to President Johnson," September 23. Foreign Relations of the United States, 1964-1968. Document 150.

Bundy, William. 1963. "Letter from William Bundy to Robert Kastenmeier." John F. Kennedy Presidential Library and Museum, White House Central Subject Files, Box 636, Folder ND 19.

Bush, George W. 2005. "President Tours Border, Discusses Immigration Reform in Texas." While House Press Conference Transcript. Retrieved July 2, 2012 (http://georgewbushwhitehouse.archives.gov/news/releases/2005/11/20051129-2.html).

Buxton, Julia. 2006. The Political Economy of Narcotics: Production, Consumption, and Narcotics. London: Zed Books. 
Chicago Tribune. 1983. "Dow Says U.S. Knew Agent Orange Hazards." Chicago Tribune, May 6, pp. 12. (ProQuest Historical Newspapers).

Cohen, Stanley. 2001. States of Denial: Knowing about Atrocities and Suffering. Cambridge: Polity Press.

Coleman, Kim. 2005. A History of Chemical Warfare. Basingstoke, UK: Palgrave Macmillan.

Committee on Foreign Relations. 1971. "Geneva Protocal of 1925." Hearing before the Committee on Foreign Relations of the U.S. Senate. Hearing ID: HRG-1971-FOR-0004 (LexisNexis Congressional).

Cooper, Neil. 2011. "Humanitarian Arms Control and Processes of Securitization: Moving Weapons Along the Security Continuum." Contemporary Security Policy 32: 134-158

Courier-Mail. 1988. "US Hits Drug Problem at its Source--in the Fields." Courier-Mail, April 30 (LexisNexis Academic).

Department of State. 1961. "Telegram From the Department of State to the Embassy in Saigon," December 14. Foreign Relations of the United States, 1961-1963. Document 321.

Dion, Michelle L. and Catherine Russler. 2008. "Eradication Efforts, the State, Displacement, and Poverty: Explaining Coca Cultivation in Colombia during Plan Colombia." Journal of Latin American Studies 40: 399-421.

Dower, John W 1987. War Without Mercy: Race and Power in the Pacific War. New York: Pantheon Books.

Downey, Liam, Eric Bonds, Katherine Clark. 2010. "Natural Resource Extraction, Violence, and Environmental Degradation." Organization \& Environment 23: 417-445.

Earth Justice. 2002. "Aerial Herbicide Spraying Violates Human Rights of Peasants and Indigenous Communities in Colombia and Ecuador." Earth Justice. Retrieved January 12, 2011 (http://earthjustice.org/news/press/2002/aerial-herbicide-spraying- violates-humanrights-of-peasants-and-indigenous-communities-in-colombia-and- ecuador).

-----. 2011. "Time to End the Fumigation in Colombia." Earth Justice. Retrieved April 3, 2011. (http://earthjustice.org/features/time-to-end-the-fumigation-in-colombia).

EPA. 2002. "Consultation Review of the Use of Pesticide for Coca Eradication in Colombia." Environmental Protection Agency. Retrieved October 6, 2010 (www.state.gov/p/inl/rls/rpt/aeicc/13237.htm).

Farmer, Ben. 2009. "Britain to Continue Poppy Eradication in Afghanistan Despite US Reversal." The Telegraph, June 28. Retrieved January 31, 2012 (www.telegraph.co.uk/news/worldnews/asia/afghanistan/5674309/Britain-to-continuepoppy-eradication-in-Afghanistan-despite-US-reversal.html).

Finnemore, Martha. 1996. National Interests in International Society. Ithaca, NY: Cornell University Press.

Forero, Juan. 2001. "No Crops Spared in Colombia's Coca War." The New York Times, January 31, pp. A1 (LexisNexis Academic).

Frankel, Max. 1965. "US Reveals Use of Nonlethal Gas Against Vietcong." The New York Times. Vietnam Center Archive. Record \#2250210018.

Gilpatric, Roswell. 1961. "Defoliant Operations in Vietnam," November 21. Vietnam Center Archives. Record \#2520306017

GAO. 2008. Plan Colombia. Government Accountablity Office Report \# GAO-09-71. Retrieved October 7, 2010 (http://www.gao.gov/cgi-bin/getrpt?GAO-09-71).

Gramsci, Antonio. 1971. Selections from the Prison Notebooks. New York: International Publishers. 
Harvey, David. 2004. The New Imperialism. New York: Oxford University Press.

Horning, Donald. 1965. "Authority to Use Tear Gas in Vietnam," September 17. Vietnam Center Archive. Record \#3670812004.

Howard, Michael. 1994. "Constraints on Warfare." Pp. 1-11 in The Laws of War, edited by Michael Howard, George Andreopoulos, and Mark Shulman. New Haven, CT: Yale University Press.

ICRC. 2011. Protocol for the Prohibition of Asphyxiating, Poisonous, and Other Gases. International Committee for the Red Cross. Retrieved March 31, 2011 (http://www.icrc.org/ihl.nsf/full/280?opendocument).

Johnson, Catherine, Timothy J. Dowd, Cecilia L. Ridgeway. 2006. "Legitimacy as a Social Process." Annual Review of Sociology 32: 53-78.

Johnson, Linden B. 1965. "Letter from President to Senator Mike Mansfield," April 12. Vietnam Center Archive. Record \#0240123012.

Joint Chiefs. 1963. "Memorandum From the Joint Chiefs of Staff to the Secretary of Defense," April 17. Foreign Relations of the United States, 1961-1963. Document 93.

Kastenmeier, Robert W. 1963. "Letter from Robert Kastenmeier to President Kennedy." John F. Kennedy Presidential Library and Museum, White House Central Subject Files, Box 636, Folder ND 19.

Klare, Michael T. 2004. Blood and Oil: The Dangers and Consequences of America's Growing Dependency on Imported Petroleum. New York: Henry Holt and Company.

Koo, Jeong-Woo and Francisco O. Ramirez. 2009. "National Incorporation of Human Rights: Expansion of National Human Rights Institutions 1966-2004." Social Forces 87: 13211353.

Landay, Jonathon S. 2007. "Outcry Against Poisoning Afghanistan Poppies." Seattle Times, Oct 26. Retrieved June 28, 2012 (http://seattletimes.nwsource.com/html/nationworld/ 2003975490 poppy26.html).

Le Billon, Philippe. 2001. "The Political Ecology of War: Natural Resources and Armed Conflicts." Political Geography 20: 561-84.

Lescaze, Lee. 1968. "U.S. Study Finds Defoliant Harmless." Washington Post, Times Herald, September 21, pp. A1. ProQuest Historical Newspapers.

Livingston, Grace. 2004. Inside Columbia: Drugs, Democracy and War. New Brunswick, NJ: Rutgers University Press.

MacNamara, Robert. 1962. "Memorandum From the Secretary of Defense (McNamara) to the President," August 8. Foreign Relations of the United States, 1961-1963. Document 262.

Margolis, Howard. 1965. "Viet Gas Use Raises Questions." The Washington Post, Times Herald, March 24, pp. A2. (ProQuest Historical Newsapers).

Mohr, Charles. 1965. "US Spray Planes Destroy Rice in Vietcong Territory." The New York Times, December 21, pp. 1. (ProQuest Historical Newspapers).

Murrow, Edward R. 1962. "Memorandum From the Director of the United States Information Agency (Murrow) to the President's Assistant for National Security Affairs (Bundy)" August 16 1962. Foreign Relations of the United States, 1961-1963. Volume II, Vietnam, 1962, Document 266.

New York Times. 1965. "Ex-Aide Scores U.S. on Tear Gas in War." The New York Times, September 23, pp. 32. (ProQuest Historical Newspapers).

-----. 1966a. "29 Scientists Score Use of Chemicals on Vietcong Crops." The New York Times, January 17, pp. 4. (ProQuest Historical Newspapers). 
-----. 1966b. "US Tells of Crop Destruction in South Vietcong." The New York Times, March 10, pp. 9. (ProQuest Historical Newspapers).

-----. 1969. "Pentagon Restates Policy Favoring Vietnam Tear Gas." The New York Times, September 25, pp. 11. (Proquest Historical Newspapers).

----. 1970. "U.S. and Mexico Plan a Drive Against Narcotics." The New York Times, March 12 , pp. 28. (ProQuest Historical Newspapers).

Oka, Takashi. 1966. "Controls Pinpoint Vietnam Defoliation." The Christian Science Monitor, March 28. Vietnam Center Archive.

Onis, Juan de. 1969. "Mexico to Reopen Drug Curb Talks." The New York Times, October 11, pp. 11. (ProQuest Historical Newspapers).

O'Toole, Thomas. 1967. "Chemical Warfare in Vietnam Called a Failure." The Washington Post, November 13, pp. A2. (ProQuest Historical Newspapers).

Parker, Geoffery. 1994. "Early Modern Europe." Pp. 40-58 in The Laws of War, edited by Michael Howard, George Andreopoulos, and Mark Shulman. New Haven, CT: Yale University Press.

Pauker, Sheridan. 2003. "Spraying First and Asking Questions Later: Congressional Efforts to Mitigate the Harmful Environmental, Health, and Economic Impacts of U.S.-Sponsored Coca Leaf Fumigation in Mexico." Ecology Law Quaterly 30: 661-692.

Price, Richard M. 1997. The Chemical Weapons Taboo. Ithaca, NY: Cornell University Press.

Raymond, Jack. 1965. "Weed Killers Aid War on Vietcong." The New York Times, March 28, pp. 2. (ProQuest Historical Newspapers).

Rejali, Darius. 2007. Torture and Democracy. Princeton, NJ: Princeton University Press.

Reinhold, Robert. 1969. "Scientists Call for a Ban on 2 Vietnam Defoliants." The New York Times, December 31, pp. 10. (ProQuest Historical Newspapers).

Riding, Alan. 1980. "Mexico Making Progress in War on Cultivation of Opium Poppies." The New York Times, February 24, pp. 12.

Risse, Thomas, Stephen C. Ropp, and Kathryn Sikkink. 1999. The Power of Human Rights: International Norms and Domestic Change. Cambridge: Cambridge University Press.

Ristrup, J.V. 1967. "5000 Scientists Ask Ban on Gas in Vietnam." The Washington Post, February 15, pp. A1. (ProQuest Historical Newspapers).

Roberts, Adam. 1994. "Land Warfare: From Hague to Nuremberg." Pp. 116-139 in The Laws of War, edited by Michael Howard, George Andreopoulos, and Mark Shulman. New Haven, CT: Yale University Press.

Robberson, Tod. 2001. "U.S. Anti-Drug Strategy Accused of Killing Colombian Food Crops." Dallas Morning News, February 21. (LexisNexis Academic).

Rusk, Dean. 1962. "Memorandum From the Secretary of State to the President," August 23. Foreign Relations of the United States, 1961-1963. Document 270.

Sikkink, Kathryn. 2011. The Justice Cascade: How Human Rights Prosecutions are Changing World Politics. New York: W.W. Norton \& Company.

Smith, Gerard C. 1969. "Memorandum From the Director of the Arms Control and Disarmament Agency (Smith) to the President's Assistant for National Security Affairs (Kissinger)," February 13. Foreign Relations of the United States, 1969-1976. Volume E-2, Documents on Arms Control and Nonproliferation, 1969-1972. Document 65.

State Department. 2002. "Memorandum of Justification Concerning Determination on Health, Environmental, and Legal Aspects of Coca Eradication in Colombia." Retrieved October 7, 2010 (http://www.state.gov/p/inl/rls/rpt/aeicc/13232.htm). 
-----. 2003. "Memorandum of Justification Concerning the Aerial Eradication of Coca and Opium Poppy in Colombia." Retrieved October 7, 2010 (www.state.gov/p/inl/rls/rpt/ aeicc/27484.htm).

-----. 2006. "Policy and Program Development: International Narcotics Control Strategy Report." Retrieved October 7, 2010 (www.state.gov/p/inl/rls/nrcrpt/2006/vol1/html/ 62103.htm).

-----. 2007. "Chemicals Used for the Aerial Eradication of Illicit Coca in Colombia and Conditions of Application." Retrieved October 7, 2010 (www.state.gov/p/inl/rls/rpt/aeicc/ 111210.htm).

Stellman, Jeanne M., Steven D. Stellman, Richard Christian, Tracy Weber, and Carrie Tomasallo. 2003. "The Extent and Pattern of Usage of Agent Orange and Other Herbicides in Vietnam." Nature 422: 681-687.

Steuter, Erin and Deberah Wills. 2008. At War with Metaphor: Media, Propaganda, and the War on Terror. Lanham, MA: Lexington Books.

Stavrianakis, Anna. 2011. "Small Arms Control and the Reproduction of Imperial Relations." Contemporary Security Policy 32: 193-214.

Tannenwald, Nina. 2007. The Nuclear Taboo: The United States and the Non-Use of Nuclear Weapons Since 1945. Cambridge: Cambridge University Press.

USIA. 1965. "Transcripts of Press Conference Given by Secretary of State Dean Rusk Regarding the Use of Tear Gas in Viet-Nam," March 24. Vietnam Center Archive. Record \#2120405023.

-----. 1967. "Vietnam in Perspective." US Information Agency Talking Points Paper No. 35, December 28. Vietnam Center Archive. Record \#212020911018.

Wallerstein, Immanuel. 1995. After Liberalism. New York: The New Press.

----. 2003. "U.S. Weakness and the Struggle for Hegemony." Monthly Review 3(55).

-----. 2004. World Systems Analysis: An Introduction. Durham, NC: Duke University Press.

-----. 2011. Centrist Liberalism Triumphant, 1789-1914. Berkeley: University of California Press.

Warren, William F. 1968. A Review of the Herbicide Program in South Vietnam. Scientific Advisory Group Working Paper No. 10-68. Vietnam Center Archive. Record \#2520308007A.

Washington Post. 1972. "U.S. Jets Drop Tear, Nausea Gas in Vietnam." The Washington Post, July 13, pp. A33. (Proquest Historical Newspapers).

-----. 1974. "Ford Sets Curbs on War Chemicals." The Washington Post, December 11, pp. A9. (Proquest Historical Newspapers).

Wilson, George C. 1969. "CS Gas Purchase for Vietnam Increased 16-fold Since '64." The Washington Post, July 24, pp. A6. (ProQuest Historical Newspapers).

Witness for Peace. 2002. "Crop Dusting Columbia." Retrieved January 12, 2011 (www.witnessforpeace.org/article.php?id=127).

Woods, Chris and Christina Lamb. 2012. "Obama Terror Drones: CIA Tactics in Pakistan Include Targeting Rescuers and Funerals." Bureau of Investigative Reporting, February 4. Retrieved February 26, 2013 (http://www.thebureauinvestigates.com/2012/02/04/ obama-terror-drones-cia-tactics-in-pakistan-include-targeting-rescuers-and-funerals/).

Wotipka, Christine Min and Kiyoteru Tsutsui. 2008. "Global Human Rights and State Sovereignty: State Ratification of Human Rights Treaties, 1965-2001." Sociological Forum 23: 724-754. 